\title{
Küresel İlim Değişikliğinin Olumsuz Etkilerine Karşı Ümitvar Baklagiller Olarak Mürdümük (Lathyrus sativus L.) ve Burçak (Vicia ervilia L.)'ın Önemi
}

\section{Mehmet ARSLAN ${ }^{* 1}$}

\section{${ }^{1}$ Akdeniz Üniversitesi, Antalya}

Öz: Bu derlemenin amacı küresel iklim değişikliği tehdidi koşullarında, gıda güvenliği açısından ümitvar bitkiler olan mürdümük ve burçak hakkında bilgi vermektir. İklim değişikliği gıda kullanımı, gıdaya erişebilmek, gıdayı işlemek ve gıda sistemindeki devamlıık gibi konuları kapsayan gıda güvenliğini ciddi şekilde etkilemektedir. Çevre ve gıda güvenliğine olan ilginin artmasıyla birlikte, ekstrem çevre ve iklim koşullarına adapte olabilecek umut veren bitkilerin önemi her zamankinden daha da artmaktadır. Mürdümük (Lathyrus sativus) ve burçak (Vicia ervilia) iklim değişikliği ve gıda güvenliğine karşı potansiyel alternatif olan iki ümitvar baklagillerdir. Her iki bitki türü de kuraklık, tuzluluk ve sel baskını gibi ekstrem çevre koşullarına toleranslıdır. Mürdümük kurak alanların inmal edilmiş bitkisi olarak bilinmekte ve cansız (abiyotik) stres faktörlerinin etkisi altında bile iyi düzeyde ürün bitki verebilmektedir. Burçak ise kısa, gür ve çalı tipi gelişme özelliği ile Akdeniz iklim kuşağında yem bitkisi olarak değerlendirilmektedir.

Anahtar Kelimeler: Küresel iklim değişikliği, baklagil, mürdümük, burçak

Importance of Grass Pea (Lathyrus sativus L.) and Bitter Vetch (Vicia ervilia L.) as Promising Legumes against of Global Climate Change

\begin{abstract}
Aim of this review is introduce to grass pea and bitter vetch as promising crops in terms of food safety under the threat of global climatic change. Climate changes have serious impacts on food security which comprise food availability, food accessibility, food utilization and food system stability. Together with an increasing concern on environment and food security the importance of promising plants which can be adapted extreme environmental and climatic conditions is more increasing than ever. Grass pea (Lathyrus sativus) and bitter vetch (Vicia ervilia) are two promising and alternative legume plants for potential climate change and food security. Both species are also resisting to extreme environment conditions as drought, salinity and flood. Grass pea, an orphan legume of the arid areas is a good alternative crop to be an important 'insurance crop' in areas that are prone to abiotic stresses Bitter vetch is a short, bushy grain legume grown today as a forage crop mainly in Mediterranean-type climates.
\end{abstract}

Keywords: global climate change, legumes, grass pea, bitter vetch

\section{Giriş}

İklim, belirli bir bölgede yeryüzünün alt yüzey atmosferinin karakteristik koşullarını belirtir. Hava durumu ise aynı yerde bu koşullardaki günlük dalgalanmaları ifade eder. Günlük hava olaylarını ölçmek için meteorologlar tarafından yaygın olarak kullanılan değişkenler hava sıcaklığı, yağış, atmosferik basınç ve nem, rüzgar ve güneş ve bulut örtüsüdür (Hanjra ve Qureshi, 2010).

"iklim Değişikliği" terimi konusunda uluslararası olarak kabul edilmiş kesin bir tanım veya ifade yoktur. İklim değişikliği, (i) ortalama hava koşullarındaki uzun vadeli değişimleri, (ii) değişim tetikleyicisi ile değişikliklerin kendilerini ve etkilerini içeren iklim sistemdeki bütün değişimleri (iii) iklim sistemindeki yalnızca insan kaynaklı değişiklikleri ifade edebilir. Benzer şekilde, iklim değişkenliği teriminin nasıl tanımlanacağı konusunda da bir mutabakat yoktur. İklim, dünyadaki 4.5 milyar yıllık tarih boyunca sürekli bir değişim halindedir, ancak bu değişikliklerin çoğu astronomik veya jeolojik zaman ölçeğinde gerçekleşmekte ve insan ölçeğinde gözlemlenemeyecek kadar yavaştır. Dünya Gıda Örgütü (FAO: Food and Agriculture Organization of the United Nations) iklim değişikliği ve gıda güvenliğini değerlendirmek için, tüm önemli iklim değişkenleri için uzun vadeli ortalamalardaki değişimleri içeren kapsamlı bir iklim değişikliği tanımını kullanmayı tercih etmektedir (Anonim 1992).

Küresel iklim modelleri, önümüzdeki yıllarda atmosferik sera gazlarının etkilerinin artmasını öngörmektedir (Hekimoğlu ve Altındeğer 2008). Nüfus artışı, ekonomik kalkınma, enerji ve arazi kullanım değişikliği beklentileri, bu yüzyılın sonuna kadar ortalama 1.5 ile $5.8{ }^{\circ} \mathrm{C}$ arasında değişen ortalama bir sıcaklık artışını öngörmektedir. Çünkü, daha sıcak bir atmosfer daha fazla su buharı tutabildiğinden, ortalama küresel yağışta \%5 ile \%15 oranında bir artış olacağını tahmin edilmektedir (IPCC 2014; Silva 2015). Ekstrem hava olayları çok yüksek sıcaklık, aşırı sağanak yağmurlar ve kuraklık durumlarını içermektedir. İlerlemiş bir sera etkisi altında, hem iklim parametrelerinde hem de aşırı meteorolojik olayların sıklığında değişim meydana gelebilir. Sera gazları, toprak yüzeyinden uzaya geri gönderilecek olan yansıyan radyasyonu absorbe ederler. Bu gazların bileşimi ve karışımı, yeryüzünde yaşamı mümkün kılsa da, insan faaliyetleri sonucu meydana gelen iklim değişikliği ile hem atmosferin bileşimi hem de gazların

Sorumlu Yazar: mehmetarslan@akdeniz.edu.tr

Geliş Tarihi: 8 Ağustos 2018

Kabul Tarihi: 2 Mayıs 2019 
karışımı etkilenmektedir (Türkeş ve ark., 2000; Kadıoğlu 2012).

Ortalama küresel sıcaklıklar, özellikle atmosferde sera gazlarının birikimi nedeniyle yaklaşık 1850 yılından beri artmaktadır (Türkeş 2001). Günümüzde ve gelecekte enerji kullanımı için ormanların yok edilmesi ve fosil yakıtların kullanılması global çevrede, tarımda ve insanlar için düşük maliyetli ve yüksek kaliteli gıdaların üretilmesinde ciddi derecede etkili olabilir. Bireysel çiftçilerin ve tüketicilerin küresel ve bölgesel iklim değişikliklerinden etkilenmesi beklenmektedir (Karaca ve ark. 1995). Küresel ısınma süreci, hiç bir azalma işareti göstermemekte ve hava koşullarında uzun vadeli değişiklikler getirmesi beklenmektedir (Rubiales ve Mikic, 2015).

Fosil yakma ve ormanların tahrip edilmesi de dahil olmak üzere insan faaliyetleri, iklim değişikliğine neden olan atmosferdeki sera gazlarının konsantrasyonunu arttırmakta ve hidrolojik döngülerin bozulmasına neden olmaktadır. Özellikle, atmosferik $\mathrm{CO}_{2}$ 'nin bu yüzyılın sonuna kadar 7301000 ppm'e ulaşması beklenmekte ve bununda aynı zamanda 1.0-3.7 ${ }^{\circ} C^{\prime}$ lik küresel ortalama yüzey sıcaklığı artışına katkıda bulunacağı tahmin edilmektedir. Yağış tahmin modelleri, zaten kurak olan bölgeler için daha sık görülen kuraklık gibi iklim değişikliği farklılıklarını tahmin etmektedir (IPCC 2014). Bu iklim değişikliği faktörleri, bitkileri fizyolojik, morfolojik, geliştirme süreçleri ve moleküler fonksiyonlarının seviyeleri bakımından etkilemektedir (Rubiales ve Mikic 2015).

Iklim değişikliği, su kaynakları ve intiyaçlarındaki değişiklikler, bitki verimliliği ve maliyeti üzerindeki etkiler, ve iklim değişikliğine uyum için gerektirdiği yüksek maliyetler nedeniyle küresel gıda güvenliği ve barışı için önemli tehditler oluşturmaktadır (Bayraç 2016). Artan dünya nüfusunun beslenmesi için yeterli gıdayı üretmek, özellikle de iklim değişikliğinin öngörülemeyen sonuçlarının tehdidi altındaki tarım için büyük bir sorundur (Abberton ve ark. 2016). İklim değişikliği belirli bir bölgede hava koşullarını, yağış rejimlerini, sıcaklığı ve $\mathrm{CO}_{2}$ yoğunluğunu değiştirebilir (Rosenzweig ve ark. 2001; Batley ve Edwards 2016). Bu değişiklikler bitkilerde abiyotik stresin, zararlıların ve patojenlerin görülme oranının artmasına ve sonuçta olarak da ürün veriminin azalmasına yol açabilir. Geçtiğimiz onlarca yıldır artan bitkisel üretim, agronomik uygulamaların geliştirilmesi ve bitki ıslahı ile geliştirilen yeni çeşitler yoluyla elde edilmiştir (Edwards 2016).

İklim değişikliğinin tarım üzerindeki olası etkileri, sadece beklenen iklim parametrelerinin ortalama değerlerine ilişkin olmayıp, meydana gelebilecek ekstrem olayların olasılığı, sıklığı ve şiddetine de bağlıdır. Iklimsel olayların zamanı ve etkilediği alanların dağılımı toprak koşullarını, suyun kullanılabilirliğini, tarımsal verimi, hastalık ve zararlıların 98 yoğunluğunu etkileyebilir. Bitkilerin çoğu yüksek sıcaklık, azalan yağış ve nem ile sel baskını gibi direkt etkilere karşı duyarlıdır. Toprak neminin ana kaynağı olan yağış, genellikle bitkilerin verimliliğini belirleyen en önemli faktör olup yağışın dönemsel dağılımı ürün verim ve kalitesindeki varyasyonun önemli bir nedenidir (Scheben ve ark. 2016).

Diğer yandan, tahminlere göre net sulama gereksinimleri 2080 yılına kadar \%45 oranında artabilir. Sulama verimliliğinde iyileştirmeler olsa dahi ve iklim değişikliği olmadan, brüt su kullanımında \%20 oranında artış olacağı tahmin edilmektedir. Simülasyonlar, iklim değişikliğinin sulama suyu gereksinimlerine olan küresel etkilerinin, sosyo-ekonomik kalkınma nedeniyle sulamada öngörülen artış kadar büyük olabileceğini göstermektedir (Parry ve ark., 2001).

Bu değişiklikler, gıda güvenliği, gıda erişilebilirliği, gıda kullanımı ve gıda sistemi istikrarı gibi dört unsur üzerinde ciddi etkilere sahip olacaktır. Bu etkiler, küresel gıda pazarlarında ve bitkisel üretimin zorlaştığı ve verimlerin düştüğü özel kırsal alanlarda önemli düzeyde hissedilmektedir. Ayrıca, birçok kırsal ve kentsel yerleşim yerlerinde bu etkiler hissedilecektir (Parry ve ark., 2001). Çünkü, tedarik zincirlerinin bozulduğu, piyasa fiyatlarının arttığı, varlıkların ve geçim olanaklarının kaybolduğu, satın alma gücünün düştüğü, insan sağlığının tehlikede olduğu ve etkilenen kişilerin baş edemediği durumlar ortaya çıkabilir (Bayraç 2016). Her türlü tarımsal üretim modelleri üzerindeki etkiler geçim kaynaklarını ve gıda erişimini etkileyecektir. Gelişmekte olan ülkelerde kırsal alanlardaki üretici gruplar iklim değişikliği ile baş edemezlerse, gıda güvenliğini ve refah düzeyini tehlikeye atacaktırlar. İklim değişikliğinin hafifletilmesi tarımsal verimliliği ve gıda güvenliği üzerinde önemli pozitif etkilere sahip olabilir. Küresel iklim değişikliğinin beraberinde getirdiği stres ortamlarında, gıda güvenliği açısından adaptasyon yeteneği yüksek bitkilerin ön plana çıkmaya başladığı görülmektedir. Baklagiller familyasına ait, ihmal edilmiş veya az kullanılmakta olan bazı ümitvar bitkiler hem insan beslenmesinde hem de hayvan beslenmesinde kritik öneme sahiptir.

\section{ÜMITVAR BAKLAGILLER}

Baklagillerin yaygın kullanımı, bu bitkileri hayvan ve insan beslenmesinde önemli bir lipid, yağ asidi ve protein kaynağı haline getirmiştir (Yoshida ve ark. 2009). Bilimsel literatür, baklagillerin hem besinsel koruyucu rolü hem de tercih edilir düzeyde yağ asidi içeriği kolestrol ve glycemic indeksi azaltıcı özelliğini göstermektedir (Pirman ve Stiblij 2003). Diğer bazı araştırma sonuçları ise, kardiyovasküler hastalıklar, diyabet ve kanser gibi kronik hastalıkların daha iyi yönetilmesi ve daha sağlıklı yaşam için baklagil tüketiminin arttırılması gerektiğini göstermektedir (Chavan 
ve ark. 2003). Bu nedenle, Lathyrus türleri de dahil olmak üzere bazı Leguminosae ailesi türlerine büyük ilgi gösterilmiş ve biyokimyasal bileşenleri (protein, yağ, yağ asitleri, flavonoidler) araştırılmıştır (Akpınar ve ark. 2001). Mürdümük (Lathyrus sativus) ve burçak (Vicia ervilia), ağırlıklı olarak hayvan beslemede kullanılan, dünyanın sert ve marjinal iklim ve çevre şartlarına sahip bölgelerinde elzem bitkiler olarak önemli bir role sahiptir (Deikman ve ark. 2012; Araujo ve ark. 2015).

\section{Mürdümük (Lathyrus sativus L.)}

İnsanların sağlıklı beslenmesi tamamen bitkisel kaynaklı besinlerine bağlıdır. Bitkiler, bütün temel besin maddelerini insanlara doğrudan veya hayvanlar tarafından tüketilmesi ve o hayvansal ürünlerin de insanlar tarafından tüketilmesi ile dolaylı olarak sağlaması açısından besin zincirinin önemli bir bileşenidir (Grusak ve DellaPenna 1999). Nüfusun kontrolsüz artışı, su kaynaklarının yetersizliği ve doğal afetlerin daha sık ortaya çıkmasıyla birlikte, gıda sorunu bazı bölgelerde kritik hale gelmiştir. Mürdümük, dünyanın kuraklığa açık bölgelerinde kuraklığa, sel taşkınlarına toleranslı popüler bir bitkidir. Mürdümük taneleri sert ve zor iklim şartlarının hakim olduğu kıtlık dönemlerinde tüketilebilecek tek gıda olma özelliğindedir (Zhao ve ark. 1999). Mürdümük tohumları hayvan beslenmesi için önemli besin maddelerinin potansiyel bir kaynağıdır (Chinnasamy ve ark. 2005).

Mürdümük cinsi (Lathyrus) baklagiller familyasında (Fabaceae/Leguminosea) yer almakta ve içerisinde tek veya çok yıllık 187 tür bulunmaktadır (Allkin ve ark. 1983). Lathyrus cinsi çok geniş alanda tür/çeşit zenginliği göstermekte olup (Jackson ve Yunus 1984), ülkemizde 18'i endemik olmak üzere 58 tür bulunmaktadır (Davis 1970). Mürdümükle ilgili yapılan çalışmalar incelendiğinde (Kendir 1999; Türk ve ark., 2007; Arslan ve ark., 2017) genellikle Doğu ve Güneydoğu Anadolu Bölgeleri'nde yayılış Çizelge 1. Mürdümük çeşit ve genotiplerinin değişik bölgelerdeki özellikleri

\begin{tabular}{llllll}
\hline $\begin{array}{l}\text { Tohum verimi } \\
(\mathrm{kg} / \mathrm{da})\end{array}$ & $\begin{array}{l}\text { Kuru ot verimi } \\
(\mathrm{kg} / \mathrm{da})\end{array}$ & $\begin{array}{l}\text { Bitki boyu } \\
(\mathrm{cm})\end{array}$ & $\begin{array}{l}\text { Ham protein } \\
\text { (ot, \%) }\end{array}$ & $\begin{array}{l}\text { Ham protein } \\
\text { (tane, \%) }\end{array}$ & Referans \\
\hline $93.18-119.20$ & $\begin{array}{l}143.71-229.28 \\
9.92(\mathrm{~g} / \mathrm{bitki})\end{array}$ & - & $21.23-24.02$ & $24.95-27.90$ & Karadag ve ark. 2004 \\
- & $180-250$ & $25-35$ & - & - & Başaran ve ark. 2011 \\
- & $390-900$ & $61-96$ & - & - & Singh ve Roy 2013 \\
- & $265-346$ & $41.2-56.7$ & - & - & Mihailovic ve ark. 2013 \\
$102-153$ & - & - & - & - & Polignano ve ark. 2009 \\
$225.7-543.4$ & $284.72-468.09$ & $67.7-105.3$ & - & - & Tavoletti ve ark. 2011 \\
$49.20-91.50$ & $24.50-31.40$ & Al-Doss ve ark. 1998 \\
\hline
\end{tabular}

Benzer şekilde, Grela ve ark. (2010), Avrupa Kıtası ülkelerinden topladığı 31 adet mürdümük hattının tohumlarında bazı zararlı bileşikler ve besin maddelerinin varyasyonunu belirlemek için çalışma yürütmüşlerdir. Çalışma sonuçlarına göre; ham protein içerikleri \%22.9 ile \%31.3 arasında, NDF içeriklerini \%11.25 ile 18.92 arasında, potasyum içeriğini $\% 0.83$ ile $\% 1.08$ arasında, $\beta$-ODAP gösterdiği, Akdeniz Bölgesi ve Orta Karadeniz Bölgesi Samsun ili çevrelerinde de görülmekte olduğu anlaşılmaktadır.

Mürdümük diğer baklagil bitkileri gibi çok değerli bir bitki olup tanelerindeki yüksek protein içeriğinden dolayı yetiştirilmektedir. Mürdümük, marjinal alanlarda kötü iklimsel şartlar altında çok fazla üretim girdisine ihtiyaç duymadan başarıyla yetiştirilebilmesinden dolayı fakir çiftçiler arasında oldukça popüler bir bitkidir (Vaz Patto ve ark., 2006; Arslan 2016). Bu bitki ekstrem kurak koşullara toleranslı olduğu gibi, aynı zamanda sel baskını gibi durumlarda köklerinin havasız ortamda kalmasına karşıda oldukça dirençlidir (Campbell ve ark., 1994). Diğer yandan, Talukdar (2011), mürdümüğün kuraklığa, soğuklara ve orta derecede tuzluluğa toleranslı bir bitki olduğunu, çok farklı iklim ve toprak tiplerinde yetişebildiğini bildirmektedirler. Bunlara ek olarak, bitkinin hastalık, zararlı ve yabancı otlarla mücadele gücü de oldukça yüksek olduğu da bilinmektedir (Das, 2000). Genetik çeşitliliği biyotik ve abiyotik stres faktörlerine dayanım noktasında ve tarımsal üretimi artırma açısından önemli bir kaynak oluşturmaktadır (Xu ve ark., 2017).

Çizelge 1'de birçok araştırmacı tarafından farklı çevre ve iklim koşullarında yetiştirilmiş mürdümük çeşit ve genotiplerinin bitkisel özellikleri, verim değerlerini ve protein içerikleri sunulmuştur. Mürdümüğün hem kuru ot verimi hem de tane veriminin oldukça yüksek olduğu, hem otunun hem de tanesinin proteince zengin olduğu da görülmektedir. Bu konuda araştırma yapan birçok araştırıcı mürdümük bitkisinin bu geniş adaptasyon yeteneğine ve kalitesine vurgu yapmaktadır. Bu bitki, küresel iklim değişikliğinin bitkisel üretimi, ciddi şekilde tehdit ettiği günümüz koşullarında, umut vaadeden bir bitki olarak dikkat çekmektedir (Fırıncıoğlu ve ark. 2004). içeriğini ise $304-1340 \mathrm{mg} / \mathrm{kg}$ arasında tespit ettiklerini bildirmişlerdir.

\section{Mürdümüğün $\beta$-ODAP İçeriği}

Bununla birlikte, birçok ülke az sayıdaki ana bitkilerin geliştirilmesi için araştırma yapmaya odaklanırken, az kullanılan ya da ihmal edilen bitkilere nispeten daha az önem vermektedir. Örneğin mürdümük, aşırı tüketildiği durumlarda beslenme bozukluklarına sebep olan bazı 
maddeler içerdiği için belirli bir dönem ihmal edilmiştir. Bunlardan en önemlisi ODAP olarak bilinen $\beta$-N-oxalyl-L$\alpha, \beta$-diaminopropionic asittir (Yan ve ark. 2006). ODAP protein yapısında olmayan serbest bir aminoasittir. Merkezi sinir sistemleri üzerinde yıkıcı etkisi nedeniyle, motor nöronlarda fonksiyon bozukluğu oluşturmakta ve lathyrism olarak bilinen hastalığa sebep olmaktadır (Jackson ve Yunus 1984). ODAP içeriğinin, mürdümük bitkisinin en önemli sorunu olduğu birçok araştırıcı (Kumar ve ark. 2011; Vaz Patto ve ark. 2006) tarafından vurgulanmaktadır.

Lathyrus türlerinin ODAP içeriği genellikle genetik olarak kontrol edilmekte olsa da çevre ve iklim şartlarından da büyük ölçüde etkilenebilmektedir. Artan ODAP miktarı ile bitkilerde kuraklığa karşı dayanımda artmakta, bu stres koşulları ile ilişkili olarak hücre zarı ve yapraklar fizyolojik işlevlerini sürdürebilmektedir (Grela ve ark. 2001; Vaz Patto ve ark. 2006; Talukdar 2011). ODAP tohumun çimlenmesiyle beraber fide gelişimi döneminden itibaren yüksek oranda bulunurken, gelişmenin ilerlemesiyle birlikte vejetatif akşamlarda azalmakta ve olgunlaşmaya doğru tamamen yok olmaktadır. Ancak, tohumda her zaman yüksek oranda ODAP bulunmaktadır (Fikre ve ark. 2008; Hanbury ark. 1999).

ODAP yoğunluğunu düşürmek için mürdümüğü methionin bakımından zengin buğdaygillerle veya soğan, sarımsak gibi antioksidan özelliği olan bitkilerle karışım halinde yetiştirmek, lathyrism hastalığının etkisini önemli düzeyde azaltmak için yeterli olabilmektedir (Getahun ve ark. 2003). Bununla birlikte, mürdümüğün zararlı etkilerinden korunabilmek için ODAP içeriği düşük çeşitlerin yetiştirilmesi büyük önem taşımaktadır (Hanbury ve ark. 2005).

\section{Burçak (Vicia ervilia L.)}

Mevcut kaba yem açığımızın giderilmesi için yem bitkileri tarımının çeşitlendirilmesi ve geliştirilmesi önemli katkılar sağlayacaktır. Tek yıllık baklagil yem bitkilerinin ekim nöbeti sistemlerine kolayca dahil olabilmesi ile toplam yem bitkileri üretimimizin artırılmasında önemli bir rol oynayacaktır. Ülkemizde karasal iklimin ve kuraklığın etkili olduğu alanlarda kışlık kaba yem ve tane yem intiyaçları karşılamakta kullanılabilecek yem bitkilerinden birisi de Çizelge 2. Burçak çeşit ve genotiplerinin değişik bölgelerdeki bitkisel özellikleri

\begin{tabular}{llllll}
\hline $\begin{array}{l}\text { Tohum verimi } \\
(\mathrm{kg} / \mathrm{da})\end{array}$ & $\begin{array}{l}\text { Kuru ot verimi } \\
(\mathrm{kg} / \mathrm{da})\end{array}$ & $\begin{array}{l}\text { Bitki boyu } \\
(\mathrm{cm})\end{array}$ & $\begin{array}{l}\text { Ham protein } \\
(\mathrm{ot}, \%)\end{array}$ & $\begin{array}{l}\text { Ham protein } \\
\text { (tane, \%) }\end{array}$ & Referans \\
\hline $56.47-312.60$ & $452.97-1069.43$ & $72.90-110.23$ & - & - & Erdurmuş ve Çakmakçı 2009 \\
134.38 & - & 36.23 & - & - & Zhelyazkova ve ark. 2016 \\
111.9 & 239.8 & 26.20 & 15.44 & 21.65 & Serin ve ark. 1997 \\
171.90 & 308.50 & - & 16.20 & 28.00 & Larbi ve ark. 2011 \\
98.23 & 351.04 & 32.27 & - & - & Bakoğlu ve Kökten 2009 \\
- & $180-600$ & - & $17-25$ & - & Kaplan ve ark. 2014 \\
- & 690 & 60.00 & - & - & Mihailović ve ark. 2006 \\
\hline
\end{tabular}

burçak (Vicia ervilia L.)'dır (Erdurmuş ve Çakmakçı 2009). Burçak Baklagiller (Leguminosae) familyasının Vicia oymağına bağı bir yem bitkisidir. Bu bitki kuvvetli kök sistemine sahip, yarı yatık şekilde gelişme gösteren ve yaklaşık $60 \mathrm{~cm}$ boylanabilen bir habitusa sahiptir (Başbağ ve Gül 2005).

Burçak, kabul edilebilir bir besleme kaynağı haline gelebilen tanesi tüketilen bitkilerden biridir. Bu bitki Akdeniz Bölgesi'nin kuru ot ve tane olarak kullanılmak üzere üretilen bir eski bir baklagil bitkisidir. Halen Akdeniz havzasında ve Yakın Doğu'da yetiştirilen küçük bir bitkidir. Akdeniz bölgesindeki genel sosyo-ekonomik dönüşümler ve bunların tarımsal üretim sistemleri üzerindeki etkilerinin, burçak bitkisini de içeren birçok türün çeşitliliği açısından genetik erozyon riski taşıdığı görülmektedir (El Fatehi ve ark. 2014). Tohumları hayvanlar için enerji ve protein açısından değerli bir kaynaktır (Reisi ve ark. 2011; Sadeghi ve ark. 2009a). Kuraklığa yüksek derecede direnci olan bu baklagil, çok sayıda yabani formu ile yetiştiricilik için çok uygundur. Biyolojik potansiyeli ile bir yem bitkisi kadar iyidir. Samanı yaygın fiğden daha fazla protein içerir ve tane verimleri genellikle daha yüksektir. Tarımsal üretimin en önemli görevlerinden birisi yem ve gıda amaçlı üretilen bitkilerin protein üretimini arttırmaktır. Bu amaçla burçak, en düşük maliyetle en yüksek miktarda protein üretmek için uygun bir bitkidir (Vateva ve Krumov, 2011).

Burçak yüksek verimli, kuraklığa ve böceklere karşı dirençli olması ve iyi enerji ve protein içeriği gibi olumlu özelliklere sahiptir. Bu da onu kanatlı hayvanların diyetleri için potansiyel ve ekonomik olarak yararlı bir yem haline getirir. Bitkinin ekimi, bakım işlemleri ve hasat edilmesi kolay olup mısır ve soya fasulyesi gibi diğer taneleri kullanılan bitkilerin başarılya yetiştirilemediği çok sığ, alkali topraklarda yetiştirilebilir (Sadeghi ve ark. 2009b). Burçak iyi ve ucuz bir protein ve enerji kaynağıdır. Taneleri bazen ruminantların beslemesinde ve kanatlı hayvanların diyetlerinde bir protein kaynağı olarak kullanıı (Haddad 2006).

Çizelge 2'de bazı araştırmacılar tarafından, değişik çevre ve iklim koşullarında burçak genotip veya çeşitleri ile yapılan çalışmalardan elde edilen, temel agronomik ve kalite 
verileri sunulmuştur. Bu değerlerden de anlaşılacağı üzere burçak genotipleri farklı iklim ve çevre koşulları altında, oldukça büyük bir varyasyon göstermektedir. Bilindiği gibi burçak, verimsiz ve su kısıtlılığının yaşandığı topraklarda, zor ve ekstrem iklim koşullarında dahi yeterli düzeyde verim elde edilebilen ihmal edilmiş bir baklagil bitkisidir.

\section{Burçağın L-Canavanine İçeriği}

Burçak tarımının gelişmemesinde ve ihmal edilmesinde önemli bir faktörde içerdiği anti-besinsel maddeler içermesidir. Rumende bulunan bazı mikroorganizmalar bu maddeleri yok ettikleri halde, tek mideli (monogastric) hayvanlarda istenmeyen bazı metabolik etkileri olduğu bulunmuştur. Bu olumsuz etkiler, L-Canavanine, lektinler, proteaz inhibitörleri ve taninler de dahil olmak üzere bazı fitokimyasal maddelerin varlığından kaynaklanmaktadır (Enneking 1995). Bununla birlikte, gözlenen toksik etkilerde L-Canavanine muhtemel rolüne özel bir dikkat çekilmektedir. L-Canavanine, virüslerden ve prokaryotlardan tüm hayvanlara kadar değişen organizmalarda güçlü anti-metabolit özellikler sergilediği bulunmuştur (Shqueir ve ark. 1989). Burçağın içerdiği en önemli toksik amino asit L-Canavanine olarak ifade edilmektedir (Berger ve ark. 2003).

Protein olmayan amino asit L-Canavanine (2-amino-4(guanidinoxy) butanoic acid), pek çok baklagil bitkisi tarafından hastalık ve zararlı etkisine karşı kimyasal bariyerinin parçası olarak depolanan güçlü bir arginin antimetabolitidir. Yeni sentezlenen proteinlere dahil edilir ve işlevsiz olmayan proteinlerin oluşumuyla sonuçlanır (Rosenthal 1977). Tek mideli hayvanlar, özellikle de tavuklar üzerinde toksik bir etkiye sahiptir. Burçak tohumlarının ortalama L-Canavanine içeriği $0.76 \mathrm{mg} / \mathrm{kg}$ olarak bildirilmektedir (Sadeghi ve ark. 2004).

Burçak tanelerinin beslenme kalitesini iyileştirmek ve kanatlı hayvanlarda güvenli bir şekilde kullanılmasını sağlamak için, toksik maddelerin yok edilmesi veya azaltılması önemlidir. Bugüne kadar denenmiş farklı işleme yöntemlerinin burçağın besin değerini arttırmak için değişik etkileri olmuştur. Örneğin, Isıl işlem, lektin ve tripsin ve proteaz inhibitörlerini inaktive etmek için etkili bir yöntemdir (Alonso ve ark. 2001). L-Canavanine nispeten yüksek sıcaklıklarda oldukça kararlı kalması nedeniyle, ısıl işlemlerle olumlu sonuçlar alınamamış ancak, suda, asitte ve alkali çözücülerde çözünebilme özelliği üzerine çalışmalar devam etmektedir (Siddhurajua ve ark. 2002).

\section{SONUÇ}

Küresel iklim değişikliğinin bitkisel üretimin giderek baskı altında kaldığı günümüz koşullarında, adaptasyon yeteneği yüksek olan mürdümük ve burçağın öneminin artacağı tahmin edilmektedir. İhmal edilmiş veya az kullanılmakta olan bu bitkiler ile iyileştirme ve çeşit geliştirme çalışmaları da çok minimal düzeyde kalmıştır. Bu bitkilerin kuraklık, tuzluluk stres şartlarına tolerans özellikleri ile gıda güvenliği açısından bir güvence olarak görülmekte olup, birçok araştırmacının ilgisini çekmeye başlamışlardır. Bu anlamda doğal florada var olan genetik materyalin erozyona uğramadan kontrol altına alınması ve bu materyallerin dahil edildiği ıslah projelerinin hayata geçirilmesi öncelikli olarak değerlendirilmelidir. Çünkü, üreticilerin ve tüketicilerin ortak beklentileri zararlı madde içermeyen yüksek verimli yeni çeşitlerdir. Yüksek verim ve kaliteye sahip yeni mürdümük ve burçak çeşitleri Akdeniz tipi iklimlerde bu bitkilerin yetiştiriciliğinde artış sağlayabilir ve kuru tarımda sürdürülebilirliğe katkıda bulunabilir. Öte yandan, bu bitkiler, küresel iklim değişikliği senaryosunun sonucunda, birçok çalışma ile dünyanın pek çok yerinde ilgi uyandırmaya devam etmektedir.

\section{KAYNAKLAR}

Abberton M, Batley J, Bentley A, Bryant J, Cai H, Cockram J, Oliveira AC, Cseke LJ, Dempewolf H, Pace CD, Edwards D, Gepts P, Greenland A, Hall AE, Henry R, Hori K, Howe GT, Hughes $S$, Humphreys $M$, Lightfoot $D$, Marshall A, Mayes S, Nguyen HT, Ogbonnaya FC, Ortiz $\mathrm{R}$, Paterson AH, Tuberosa R, Valliyodan B, Varshney RK, Yano M (2016) Global agricultural intensification during climate change: a role for genomics. Plant Biotechnology Journal: 1-4, doi: 10.1111/pbi.12467.

Akpınar N, Akpınar MA, Türkoğlu S (2001) Total lipid content and fatty acid composition of the seeds of some Vicia L. species. Food Chem.74: 449-453.

Allkin R, Macfarlance TD, White RJ, Bisby FA, Adey ME (1983) Names and synonyms of species and subspecies in the Vicieae. Issue 2, Vicieae Database ProjectPublication No. 2, Southampton.

Al-Doss AA, Assaeed AM, Soliman AS (1998) Growth Characters and Yield of Some Selected Lines of Grass Pea (Lathyrus sativus). King. Saud. Univ. Agric. Sci., 10 (1): 67-72

Alonso R, Rubio LA, Muzquiz M, Marzo F (2001) The effect of extrusion cooking on mineral bioavailability in pea and kidney bean grain meals. Animal Feed Science and Technology 94: 1-13.

Anonim, (1992) UNFCCC: UN Framework Convention on Climate Change, Article 1. Definitions. Available at: unfccc.int/resource/docs/convkp/conveng.pdf. Erişim Tarihi: 30.11.2017.

Araujo SS, Beebe S, Crespi M, Delbreil B, Gonz'alez EM, Gruber V, Lejeune-Henaut I, Link W, Monteros MJ, Prats E, Rao I, Vadez V, Vaz Patto MC (2015) Abiotic Stress Responses in Legumes: Strategies Used to Cope With Environmental Challenges. Critical Reviews in Plant Sciences, 34: 237-280

Arslan M (2016) Importance and current situation of grass pea (Lathyrus sativus L.) in forage crops production of Turkey. Turkish Journal Of Agricultural And Natural Sciences, 3 (1): 17-23.

Arslan $\mathrm{M}$, Oten $\mathrm{M}$, Erkaymaz $\mathrm{T}$, Tongur $\mathrm{T}$, Kilic $\mathrm{M}$, Elmasulu S. Cinar A (2017) $\beta$-N-oxalyl-L-2,3-diaminopropionic acid, L-homoarginine and asparagine contents in the seeds of different genotypes Lathyrus sativus L. as 
determined by UHPLC-MS/M. International Journal of Food Properties, 20 (S1): 108-118.

Bakaoğlu A, Kökten K (2009) Elazığ koşullarında burçakta (Vicia ervilia (L.) Willd.) farklı sıra aralığının verim ve verim unsurları üzerine etkisi. HR.Ü.Z.F.Dergisi, 13 (1): 7-12.

Basaran U, Asci Onal O, Mut H, Acar Z, Ayan I (2011) Some quality traits and neurotoxin ß-N-oxalyl-L- a, ßdiaminopropionic acid (ß-ODAP) contents of Lathyrus sp. cultivated in Turkey. African Journal of Biotechnology. 10: 4072-4078.

Başbağ M, Gül i (2005) Diyarbakır Koşullarında Bazı Burçak (Vicia ervilia (L.) Willd) Hatlarında Verim ve Verim Unsurlarının Belirlenmesi. HR.Ü.Z.F. Dergisi, 9 (1):1-7.

Batley J, Edwards D (2016) The Application of Genomics and Bioinformatics to Accelerate Crop Improvement in a Changing Climate. Curr. Opin. Plant Biol., 30: 78-81.

Bayraç HN (2016) Türkiye'de İklim Değişikliğinin Tarım Sektörü Üzerine Etkileri. Eskişehir Osmangazi Üniversitesi IïBF Dergisi, 11 (1): 23- 48.

Berger J, Larry D, Robertson D, Cocks PS (2003) Agricultural Potential of Mediterranean Grain and Forage Legumes: (2) Anti-nutritional Factor Concentrations in the Genus Vicia. Genetic Resources and Crop Evolution 50 (2): 201-212.

Campbell CG, Mehra RB, Agrawal SK, Chen YZ, Abd-ElMoneim, AM, Khawaja HIT, Yadav CR, Tay JU, Araya WA (1994) Current status and future strategy in breeding grass pea (Lathyrus sativus). Euphytica, 73: 167-175.

Chavan UD, Mckenzie DB, Amarowicz R, Shahidi F (2003) Phytochemical components of beach pea (Lathyrus maritimus L.). Food Chem., 81: 61-71.

Chinnasamy G, Bal AK, McKenzie DB (2005) Fatty acid composition of grass pea (Lathyrus sativus L.) seeds. Lathyrus Lathyrism Newsletter, 4: 1-4.

Das NR (2000) Lathyrus sativus in Rainfed Multiple Cropping Systems in West Bengal, Indiaa Review. Lathyrus Lathyrism Newsletter 1: 25-27.

Davis PH (1970) Flora Of Turkey and East Aegean Islands. Edinburgh: 328-369.

Deikman J, Petracek M, Heard JE (2012) Drought tolerance through biotechnology: improving translation from the laboratory to farmers' fields. Curr. Opin. Biotechnol. 23: 243-250.

Edwards D (2016) The Impact of Genomics Technology on Adapting Plants to Climate Change, in: D. Edwards, J. Batley (Eds.), Plant Genomics and Climate Change, Springer, pp. 173-178.

El Fatehi S, Béna G, Filali-Maltouf A, Ater M (2014) Variation in yield component, phenology and morphological traits among Moroccan bitter vetch landraces Vicia ervilia (L.) Wild. African Journal of Agricultural Reseach, 9(23): 1801-1809.

Enneking D (1995) The Toxicity of Vicia Species and Their Utilisation as Grain Legumes, 2nd ed. Centre for Legumes in Mediterranean Agriculture Occasional
Publication 6. Nedlands: University of Western Australia.

Erdurmuş C, Çakmakçı S (2009) Antalya Koşullarında Bazı Burçak (Vicia ervilia (L.) willd) Hatlarında Bitkisel ve Tarımsal Özelliklerin Saptanması. Akdeniz Üniversitesi Ziraat Fakültesi Dergisi, 22 (1): 113-119

Getahun H, Lambein F, Vanhoorne M, Van Der Stuyft P (2003) Food-aid to reduce neurolathyrism related to grass-pea preparations during famine. Lancet 362: 1808-1810.

Grela ER, Studzioski T, Matras J (2001) Antinutritional factors in seeds of Lathyrus sativus cultivated in Poland. Lathyrus Lathyrism Newsletter, 2:101-104.

Grela ER, Rybinski W, Klebaniuk R, Matras J (2010) Morphological characteristics of some accessions of grass pea (Lathyrus sativus L.) grown in Europe and nutritional traits of their seeds. Genetic Resource and Crop Evoluation 57:693-701

Grusak MA, DellaPenna D (1999) Improving the nutrient composition of plants to enhance human nutrition and health. Annu. Rev. Plant Physiol. Plant Mol. Biol. 50: 133-161

Fao (2017) The Food and Agriculture Organization of the United Nations. www.fao.org, Erişim tarihi: 15.12.2017.

Fırıncıoğlu HK, Ünal S, Özpınar H (2004) Grass pea (Lathyrus sativus L.) as a feed crop in mixed farming systems in Turkey. Journal of Field Crops Central Research Institute, 13(1-2): 29-36

Fikre A, Korbu L, Kuo YH, Lambein F (2008) The contents of the neuro-excitatory amino acid $\beta$-ODAP (b-N-oxalylL-a,bdiaminopropionic acid), and other free and protein amino acids in the seeds of different genotypes of grass pea (Lathyrus sativus L.). Food Chemistry, 110: 422-427.

Haddad SG (2006) Bitter vetch grains as a substitute for soybean meal for growing lambs. Live. Sci., 99: 221225.

Hanbury CD, Siddique KHM, Galwey NW, Cocks PS (1999) Genotype-environment interaction for seed yield and ODAP concentration of Lathyrus sativus $L$. and $L$. cicera L. in Mediterranean-type environments. Euphytica, 110: 445-460.

Hanbury CD, Siddique KHM, Seymour M, Jones R, MacLeod B (2005) Growing Corea grass pea (Lathyrus sativus L.) in Western Australia. Farmnote, No:58, www.agric.wa.gov.au

Hanjra MA, Qureshi ME, 2010. Global water crisis and future food security in an era of climate change. Food Policy, 35: 365-377.

Hekimoğlu B, Altındeğer M (2008) Küresel Isınma ve İklim Değişikliği. Samsun II Tarım Müdürlüğü Çiftçi Eğitimi ve Yayım Şubesi Yayını, ss: 79, Samsun.

IPCC (2014) Climate Change 2014 Synthesis Report. http://www.ipcc.ch/report/ar5/syr/, Erişim Tarihi: 15.12.2017. 
Jackson MT, Yunus AG (1984) Variation in the grass pea (Lathyrus sativus L.) and wild species. Euphytica, 33: 549-559.

Kaplan M, Uzun S, Kökten K (2014) Effects of harvest time on hay yield and quality of different bitter vetch (Vicia ervilia L.) lines. Legume Reseach, 37 (2): 188-194.

Kadıoğlu M (2012) Türkiye'de İklim Değişikliği Risk Yönetimi. Türkiye'nin İklim Değişikliği II. Ulusal Bildiriminin Hazırlanması Projesi Yayını, 172 sf.

Karaca M, Tayanç M, Toros H (1995) 'Effects of Urbanization on Climate of İstanbul and Ankara,' Atmos. Environ., 29, 3411-3421.

Karadağ Y, İptaş S, Yavuz M (2004) Agronomic Potential of Grasspea (Lathyrus sativus L.) Under Rainfed Condition in Semi-arid Regions of Turkey. Asian Journal of Plant Sciences, 3 (2): 151-155.

Kendir H (1999) Bazı Kıbrıs mürdümüğü (Lathyrus ochrus (L) DC.) hatlarının Ankara koşullarında tohum verimlerinin belirlenmesi. Tarım Bilimleri Dergisi, 5(3): 53-60.

Kumar S, Bejiga G, Ahmed S, Nakkoul H, Sarker A (2011) Genetic improvement of grass pea for low neurotoxin ( $\beta$-ODAP) content. Food and Chemical Toxicology 49: 589-600.

Larbi A, Abd El-Moneim AM, Nakkoul H, Jammal B, Hassan S (2011) Intra-species variations in yield and quality determinants in Vicia species: 1. Bitter vetch (Vicia ervilia L.). Animal Feed Science and Technology 165 :278-287.

Mihailovic V, Mikic A, Cupina B, Krstic D, Antanasovic S, Radojevic V (2013) Forage Yields and Forage Yield Components in Grass Pea (Lathyrus sativus L.). Legume Reseach, 36(1): 67-69.

Parry M, Arnell N, McMichael T, Nicholls R, Martens $P$, Kovats S, Livermore M, Rosenzweig C, Iglesias A, Fischer G (2001) Millions at risk: defining critical climate change threats and targets. Global Environmental Change 11: 181-183.

Pirman T, Stiblij V (2003) An influence of cooking on fatty acid composition in three varieties of common beans and in lentil. Eur. Food Res. Tech., 217, 498-503.

Polignano GB, Bisignano V, Tomaselli V, Uggenti P, Alba V, Della-Gata C (2009) Genotype X environment interaction in grass pea (Lathyrus sativus L.) lines. International Journal of Agronomy doi:10.1155/2009/898396

Reisi K, Zamani F, Vatankhah M, Rahimiyan Y (2011) Effect of Raw and Soaked Bitter Vetch (Vicia ervilia L) Seeds As Replacement Protein Source of Cotton Seed Meal on Performance and Carcass Characteristics of LoriBakhtiari Fattening Ram Lambs. Global Veterinaria, 7 (4): 405-410.

Rosenzweig C, Iglesias A, Yang XB, Epstein PR, Chivian E (2001) Climate change and extreme weather events:implications for food production, plant diseases, and pests. Global Change \& Human Health, 2 (2): 90-104.
Rosenthal G (1977) The biological effects and mode of action of L-canavanine, a structural analogue of Larginine. Quarterly Review of Biology 52: 155-178.

Rubiales D, Mikic A (2015) Introduction: Legumes in Sustainable Agriculture. Critical Reviews in Plant Sciences, 34:2-3.

Sabancı OC, Özpınar H (2001) Bazı yem bitkilerinin Menemen koşullarına adaptasyonları üzerine araştırmalar II. mürdümük (Lathyrus sativus L.). Anadolu Dergisi, 10 (1): 41-45.

Sadeghi GH, Samie A, Pourreza J, Rahmani HR (2004) Canavanine content and toxicity of raw and treated Bitter vetch (Vicia ervilia) grains for broiler chicken. International Journal of Poultry Science 3: 522-529.

Sadeghi G, Purreza J, Samei A, Rahmani H (2009a) Chemical composition and some anti-nutrient of raw and processed bitter vetch (Vicia ervilia L.) seed for use as feeding stuff in poultry diet. Animal Health Products, 41, 85-93.

Sadeghi GH, Mohammadi L, Ibrahim SA, Gruber KJ (2009b) Use of bitter vetch (Vicia ervilia) as a feed ingredient for poultry. World's Poultry Science Journal, 65: 5164.

Scheben A, Yuan Y, Edwards D (2016) Advances in Genomics for Adapting Crops to Climate Change. Current Plant Biology, 6: 2-10.

Serin Y, Tan M, Çelebi HB (1997) Erzurum yöresine uygun burçak (Vicia ervilia (L.) Willd.) hatlarının belirlenmesi. Tarla Bitkileri Merkez Araştırma Enstitüsü Dergisi 6 (2): 13-22.

Shqueir AA, Brown DL, Klasing KC (1989) Canavanine content and toxicity of sesbania leaf meal for growing chicks. Animal Feed Science and Technology 25: 137147.

Silva JG (2015) FAO's Work On climate change. United Nations Climate Change Conference 2015,

Singh A, Roy AK (2013) Variability for forage yielding traits in exotic grass pea (Lathyrus sativus L.). Forage Res., 38 (4): 230-233.

Siddhurajua P, Makkarb HPS, Beckera K (2002) The effect of ionising radiation on antinutritional factors and the nutritional value of plant materials with reference to human and animal food. Food Chemistry 78:187-205.

Talukdar D (2011) Morpho-Physiological responses of grass pea (Lathyrus sativus) genotypes to salt stres at germination and seedling stages. Legume Research, 34 (4): 232-241.

Tavoletti S, lommarini L, Mogliani L (2011) Agronomic, qualitative ( $\beta$-ODAP) and molecular variability in grasspea populations of the Marche region (central Italy). Food and Chemical Toxicology, 49(3): 601-606.

Türk M, Albayrak S, Çelik N (2007) Estimates of broad-sense heritability for seed yield and yield components of grass pea (Lathyrus sativus L.). Turkish Journal of Agriculture and Forestry, 31: 155-158.

Türkeş M, Sümer UM, Çetiner G (2000) 'Küresel iklim değişikliği ve olası etkileri', Çevre Bakanlığı, Birleşmiş Milletler İklim Değişikliği Çerçeve Sözleşmesi Seminer 
Notları (13 Nisan 2000, İstanbul Sanayi Odası), 7-24, ÇKÖK Gn. Md., Ankara.

Türkeş M (2001) Küresel iklimin korunması, İklim Değişikliği Çerçeve Sözleşmesi ve Türkiye. Tesisat Mühendisliği, TMMOB Makina Mühendisleri Odası, Süreli Teknik Yayın 61: 14-29.

Vateva V, Krumov V (2011) Biological and soil preserving possibilities of bitter vetch (Vicia ervilia L.) cultivated in the conditions of organic agriculture in the region of Sakar. 100 years soil science in Bulgaria, International conference 16-20 May 2011, Sofia, Scientific reports, I, 837-841.

Vaz Patto MC, Skiba B, Pang ECK, Ochatt SJ, Lambein F, Rubiales D (2006) Lathyrus improvement for resistance against biotic and abiotic stresses: From classical breeding to marker assisted selection. Euphytica (2006) 147: 133-147.
Xu Q, Liu F, Jez JM, Krishnan HB (2017) $\beta$-N-oxalyl-L-2,3diaminopropionic Acid ( $\beta$-ODAP) Content in Lathyrus sativus: The Integration of Nitrogen and Sulfur Metabolism through $\beta$-Cyanoalanine Synthase. Int. J. Mol. Sci. 18 (3): 526.

Yan ZY, Spencer PS, Li ZX, Liang YM, Wang YF, Wang CY, Li FM (2006) Lathyrus sativus (grass pea) and its neurotoxin ODAP. Phtytochemistry 67, 107-121.

Yoshida H, Saiki M, Yoshida N, Tomiyama Y, Mizushina $Y$ (2009) Fatty acid distribution in triacylglycerols and phsopholipds. Food Chem., 112: 924-928.

Zhelyazkova T, Pavlov D, Delchev G, Stoyanova A (2016) Productivity and Yield Stability of Six Grain Legumes in the Moderate Climatic Conditions of Bulgaria. Scientific Papers. Series A. Agronomy, Vol. LIX: 478487. 